\title{
Characterization of Fines Produced by Degradation of Polymetallic Nodules from the Clarion-Clipperton Zone
}

\author{
Mun Gi Kim ${ }^{1} \oplus$, Kiseong Hyeong ${ }^{1}$, Chan Min Yoo $^{2}$, Ji Yeong Lee ${ }^{3}$ and Inah Seo ${ }^{4, *}$ \\ 1 Global Ocean Research Center, Korea Institute of Ocean Science and Technology, Busan 49111, Korea; \\ mgkim@kiost.ac.kr (M.G.K.); kshyeong@kiost.ac.kr (K.H.) \\ 2 Deep-Sea Mineral Resources Research Center, Korea Institute of Ocean Science and Technology, \\ Busan 49111, Korea; cmyoo@kiost.ac.kr \\ 3 Department of Earth and Environmental Sciences, Pukyong National University, Busan 48513, Korea; \\ jylee@pukyong.ac.kr \\ 4 Department of Earth and Environmental Sciences, Jeonbuk National University, Jeonju 54896, Korea \\ * Correspondence: inahseo@jbnu.ac.kr
}

check for updates

Citation: Kim, M.G.; Hyeong, K.; Yoo, C.M.; Lee, J.Y.; Seo, I. Characterization of Fines Produced by Degradation of Polymetallic Nodules from the Clarion-Clipperton Zone. Minerals 2021, 11, 205.

https://doi.org/10.3390/min11020205

Academic Editor: Pedro Madureira

Received: 31 January 2021

Accepted: 13 February 2021

Published: 15 February 2021

Publisher's Note: MDPI stays neutral with regard to jurisdictional claims in published maps and institutional affiliations.

Copyright: (c) 2021 by the authors. Licensee MDPI, Basel, Switzerland. This article is an open access article distributed under the terms and conditions of the Creative Commons Attribution (CC BY) license (https:/ / creativecommons.org/licenses/by/ $4.0 /)$.

\begin{abstract}
The discharge of fluid-particle mixture tailings can cause serious disturbance to the marine environment in deep-sea mining of polymetallic nodules. Unrecovered nodule fines are one of the key components of the tailings, but little information has been gained on their properties. Here, we report major, trace, and rare earth element compositions of $<63 \mu \mathrm{m}$ particles produced by the experimental degradation of two types of polymetallic nodules from the Clarion-Clipperton Zone. Compared to the bulk nodules, the fines produced are enriched in $\mathrm{Al}, \mathrm{K}$, and $\mathrm{Fe}$ and depleted in $\mathrm{Mn}, \mathrm{Co}, \mathrm{Ni}, \mathrm{As}, \mathrm{Mo}$, and $\mathrm{Cd}$. The deviation from the bulk composition of original nodules is particularly pronounced in the finer fraction of particles. With X-ray diffraction patterns showing a general increase in silicate and aluminosilicates in the fines, the observed trends indicate a significant contribution of sediment particles released from the pores and cracks of nodules. Not only the amount but also the composition of nodule fines is expected to significantly differ depending on the minimum recovery size of particles at the mining vessel.
\end{abstract}

Keywords: polymetallic nodules; deep-sea mining; tailings; elemental composition

\section{Introduction}

The economic potential of polymetallic nodules (also called ferromanganese nodules) has attracted attention for more than half a century [1], but actual commercial mining has yet to take place. While the technical issues hampering their exploitation have been partially resolved over time, environmental issues have emerged [2-4]. The assessment of environmental risks is now a prerequisite for a potential polymetallic nodule mining practice. This is especially true since the nodule fields with high economic value are mostly found in areas beyond national jurisdiction [5] and thus subject to the International Seabed Authority (ISA) regulations.

A mining system design for polymetallic nodules consists of the following parts in general: a miner at the seafloor, a mining platform/vessel near the sea surface, a riser in between, and a discharge system at some depth in the water column [6]. It is envisaged that the biggest environmental impact will be caused by the miner, and that the mining platform and the riser will result in relatively minor disturbances [7]. Disturbance from the discharge system is another important yet poorly understood factor that may harm broad areas from the surface to the seafloor, both inside and outside the mining block [8,9]. A mixture of bottom water, sediment, benthic biota, and unrecovered nodule fragments will be released back to the ocean after separation processes at the surface platform $[10,11]$. One preferable strategy to avoid the most damaging outcome is to release them below the oxygen-minimum zone and the thermocline [12], but this is certainly insufficient to alleviate growing concerns on the environmental impacts of tailings discharge. 
Unrecovered fines of polymetallic nodules will constitute an important part of solids in the discharge. They will be particularly important for the nodule mining system with a hydraulic pump, which is the most used lifting method at present for prospecting $[13,14]$. Turbulence in the lifting pipe of several kilometers length will facilitate numerous collisions of friable nodules, resulting in particle failure through impact fragmentation, chipping, attrition, and/or abrasion $[15,16]$. Both environmental impact and ore loss can be minimized if all the produced particles are recovered before discharge, but a thorough separation is expensive and inefficient. In order to maintain economic feasibility of the mining, particles smaller than a certain size are bound to be released with seawater. The size of particles that cannot be efficiently recovered may differ depending on the design of the separation process, but it is expected that at least particles smaller than $8 \mu \mathrm{m}$ will be technically difficult to recover [17].

To date, only a handful of studies have examined the degradation of polymetallic nodules during a mining operation (e.g., [17-23]). Little information indeed has been provided on the particles less than few tens of micrometers in diameter, despite the fact that those small ones are actually more likely to be unrecovered and released into the ocean. Most previous studies focused only on the size reduction of nodule fragments and paid little attention to their chemistry or mineralogy. Considering that polymetallic nodules are both physically and chemically heterogeneous with numerous microlayers, inclusions, and impurities [24,25], the composition of the nodule fines produced can be largely different from that of the bulk nodules.

Focusing exclusively on the silt- and clay-sized $(<63 \mu \mathrm{m})$ fractions, we examine the particles produced by an experimental degradation of polymetallic nodules. The primary purpose of this study is to understand how the degraded particles differ from the original nodules in composition. Special attention is paid to the elements of economic interest (Cu, Ni, Co, Mn, Zn, Mo, and rare earth elements (REEs)) and environmental concern (the aforementioned elements plus $\mathrm{As}, \mathrm{Cd}$, and $\mathrm{Pb}$ ). The improved understanding on the fines will provide useful information for future environmental impact assessments and the design of environmentally acceptable mining systems.

\section{Materials and Methods}

\subsection{Experimental Setup and Procedures}

Current understanding on the degradation of the polymetallic nodules during the mining process has been gained from laboratory experiments for the most part, because in situ experiments were mostly unavailable due to high cost and regulatory constraints. Accordingly, several studies have used lift pumps reduced to a laboratory scale that mimic on-site facilities $[19,22]$, and others took a more abstracted approach by using conventional instruments such as vibrating mill, rotary mill, and ball mill [20,21]. In this study, we opted to use a planetary ball mill (Retsch PM 100), since it is particularly suitable for the investigation of small-sized particles. Particle-wall and particle-particle interactions were reproduced by a rotating agate jar filled with polymetallic nodules and water but without any ball charge. A constant sun wheel speed of $100 \mathrm{rpm}$ was used. Both frictional and impact forces act on nodules under this setting.

Two types of polymetallic nodules collected from different localities in the Korea Deep Ocean Study (KODOS) area for nodule exploration in the Clarion-Clipperton Zone (CCZ) were used for the experiment (Figure 1) [26]. Type 1 nodules are generally 9-12 cm in diameter and have discoidal shapes. Type 2 nodules are generally $3-6 \mathrm{~cm}$ in diameter and have sub-spherical shapes and smoother surface. Type 1 nodules are usually more porous and fragile, while Type 2 nodules have a relatively dense internal structure (Figure 2). These two contrasting types of nodules were selected to examine nodules formed by different processes (diagenetic vs. hydrogenetic), although all CCZ nodules are strictly mixed types consisting of both diagenetic and hydrogenetic layers. For each type, about $3 \mathrm{~kg}$ of nodules were crushed to a size smaller than $2 \mathrm{~cm}$ in diameter before the experiment, as it is a common practice for miners to crush nodules before vertical transport in order 
to prevent clogging of the pipes $[27,28]$. Five samples each were randomly taken from a gently mixed pile of crushed nodules and were completely ground for the bulk analysis; the rest of the pile was used for the degradation experiment.

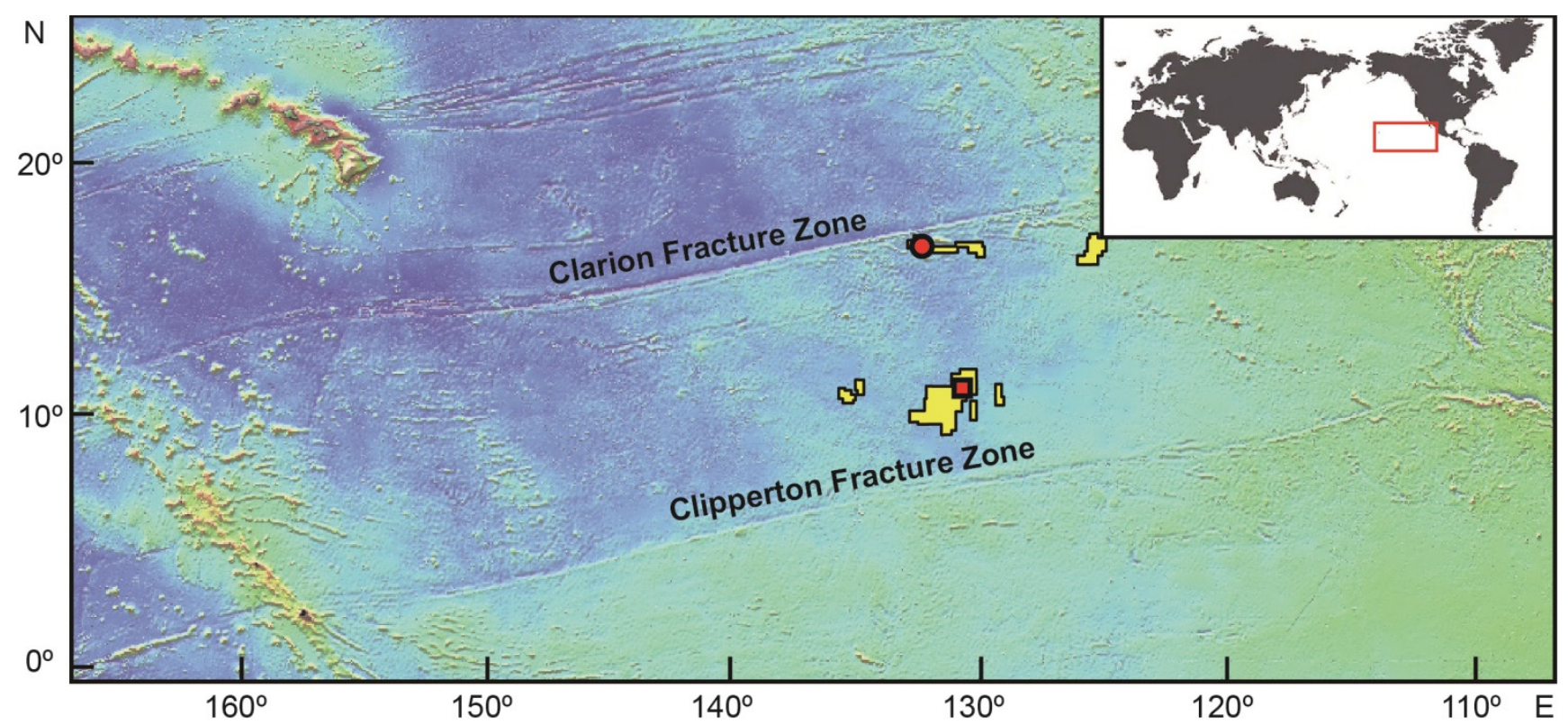

Figure 1. Map showing locations of the sampling sites of Type 1 (red rectangle) and Type 2 (red circle) nodules. Yellow area represents the Korean exploration area for polymetallic nodules.

Degradation in a planetary ball mill was carried out for 15, 25, and 35 min for each nodule type, and all the batches were run in triplicate. For each run, crushed nodules with a dry weight of $25 \mathrm{~g}$ were prepared in a $250 \mathrm{~mL}$ agate jar, which was filled with distilled water to a total of $250 \mathrm{~g}$. When the milling was over, the contents in the agate jar were wet-sieved through a $63 \mu \mathrm{m}$ sieve using distilled water. The coarse particles left in the sieve corresponded to the fraction that will be easily separated by on-board processing and thus were removed from the further analysis after dry weighing. A small part of the well-mixed suspension containing $<63 \mu \mathrm{m}$ particles was taken for particle size distribution analysis. The rest of the suspension went through further size separation for bulk chemical analysis and X-ray diffraction (XRD) analysis. Size separation into 32-63 $\mu \mathrm{m}, 16-32 \mu \mathrm{m}$, $8-16 \mu \mathrm{m}$, and $<8 \mu \mathrm{m}$ fractions was carried out by using Stoke's Law, where the settling velocity of a particle is inversely proportional to the square of its diameter. The settling time was calculated assuming a wet density of $1.9 \mathrm{~g} / \mathrm{cm}^{3}$. Withdrawal of supernatant after suspension in distilled water in a $50 \mathrm{ml}$ settling tube was repeated three times per each separation step.

\subsection{Analytical Methods}

The particle size distribution of the $<63 \mu \mathrm{m}$ fraction of each sample was analyzed using the laser diffraction method with a Malvern Mastersizer 2000. Samples were pretreated with $2 \%$ Calgon solution and were dispersed in an ultrasonic bath for 5 minutes just before the measurement to prevent agglomeration.

For elemental analysis, 20-100 mg of freeze-dried samples were each digested by a mixture of $3 \mathrm{~mL}$ hydrochloric acid $(\mathrm{HCl})$ and $0.5 \mathrm{~mL}$ hydrofluoric acid (HF) in a tightly closed Teflon vessel at $185^{\circ} \mathrm{C}$ for 36 hours. The vessel was cooled, opened, heated at $185^{\circ} \mathrm{C}$ until dryness, and a mixture of $1 \mathrm{ml}$ perchloric acid $\left(\mathrm{HClO}_{4}\right)$ and $3 \mathrm{~mL} 6 \mathrm{~N}$ nitric acid $\left(\mathrm{HNO}_{3}\right)$ was added. Then, the mixture was heated until dryness, treated with $2 \mathrm{~mL}$ $6 \mathrm{~N}$ nitric acid $\mathrm{HNO}_{3}$, heated again until dryness, and finally diluted with $2 \% \mathrm{HNO}_{3}$. 


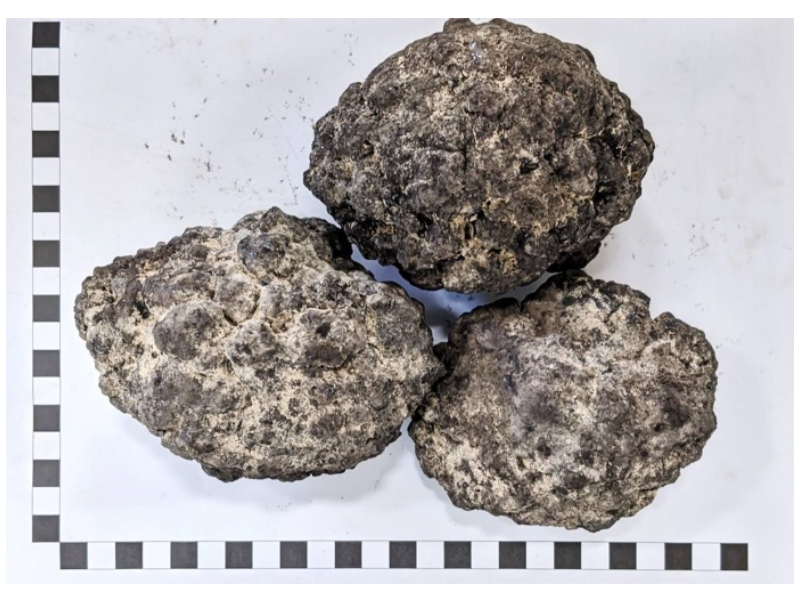

(a)

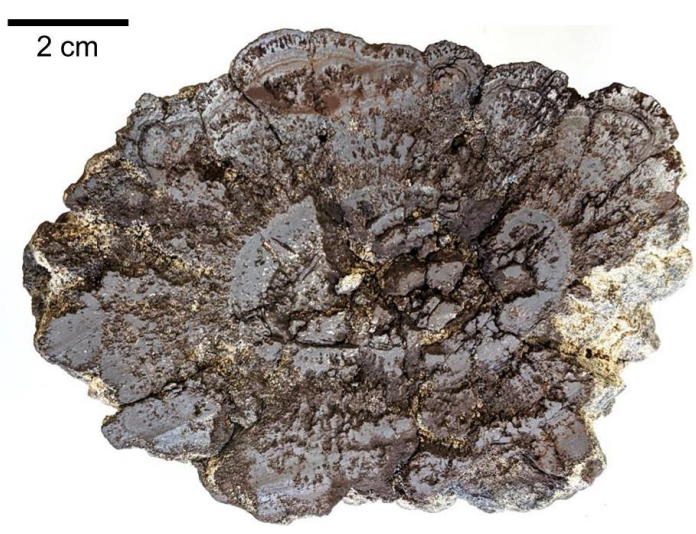

(c)

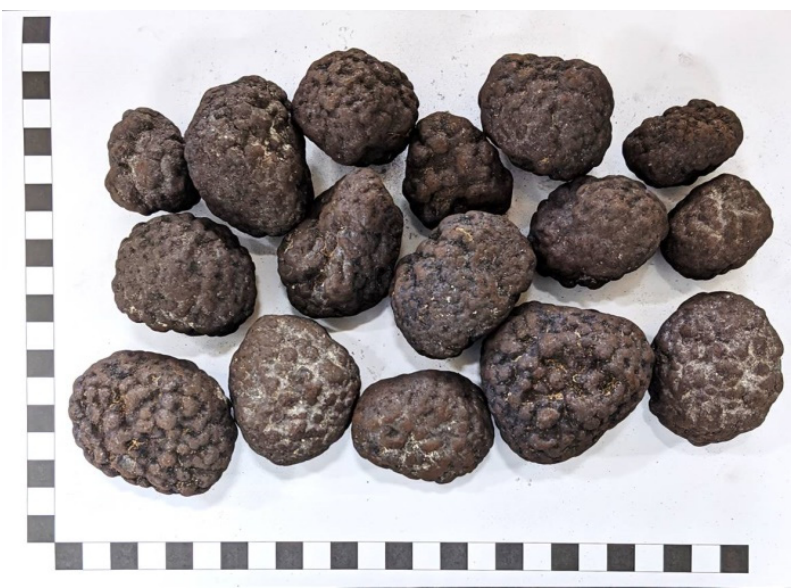

(b)

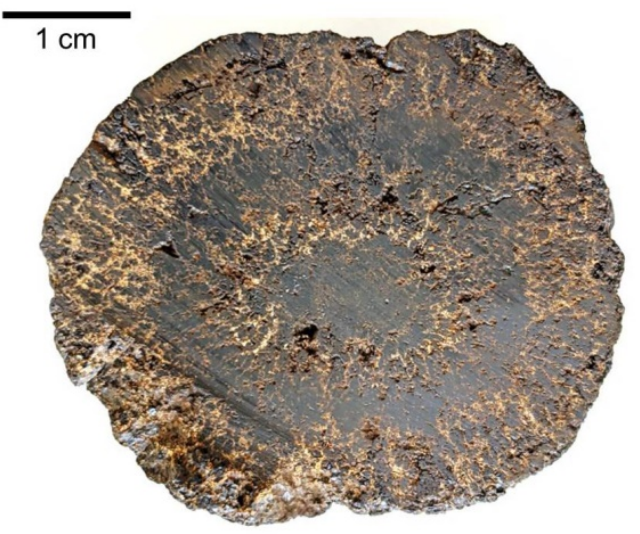

(d)

Figure 2. Typical samples of (a) Type 1 and (b) Type 2 nodules (side length of black and white squares $=1 \mathrm{~cm}$ ), and representative cross-section of (c) Type 1 and (d) Type 2 nodules.

The major element and trace element (including rare earths) compositions of the digested samples were each analyzed by using an inductive coupled plasma-optical emission spectrometry (ICP-OES, Optima 3000DV, PerkinElmer) and an inductive coupled plasmamass spectrometry (ICP-MS, PlasmaTrace, VG elemental), respectively, which were both housed at the Korea Institute of Ocean Science and Technology in Busan, Republic of Korea. One Geological Survey of Japan standard (JMn-1) and two United States Geological Survey standards (NOD-A-1 and NOD-P-1) were used as certified reference materials. Analytical results for three standard materials were generally within $\pm 5 \%$ of reference values for each element.

The mineralogy of the bulk nodules and nodule fines were analyzed with a PANalytical X'pert Pro X-ray diffractometer housed at the Korea Institute of Ocean Science and Technology, using $\mathrm{Cu}-\mathrm{K} \alpha$ radiation generated at $40 \mathrm{kV}$ and $20 \mathrm{~mA}$. The powdered samples were scanned from $3^{\circ}$ to $70^{\circ}$ with a step size of $0.02^{\circ}$ and a measuring speed of $1^{\circ}$ per minute at room temperature.

\section{Results}

\subsection{Particle Size Distribution}

Size distributions of $<63 \mu \mathrm{m}$ particles from polymetallic nodules show a gradual increase in proportion of finer particles over time (Figure 3), indicating progressive production of the fines during the experiment. Volume fractions of $<8 \mu \mathrm{m}$ particles among total $<63 \mu \mathrm{m}$ particles produced by initial crushing of Type 1 and Type 2 nodules were $24.5 \%$ and $19.5 \%$, respectively. They increased to $33.8 \%$ and to $25.4 \%$ after $15 \mathrm{~min}$ of degradation 
in a planetary ball mill, and after $35 \mathrm{~min}$, they increased further to $38.7 \%$ and to $27.8 \%$, respectively. Median sizes (in volume basis) of total $<63 \mu \mathrm{m}$ particles derived from Type 1 and Type 2 nodules were initially 22.5 and $25.8 \mu \mathrm{m}$, but they decreased to 13.3 and $16.8 \mu \mathrm{m}$, respectively, after $35 \mathrm{~min}$ of degradation.

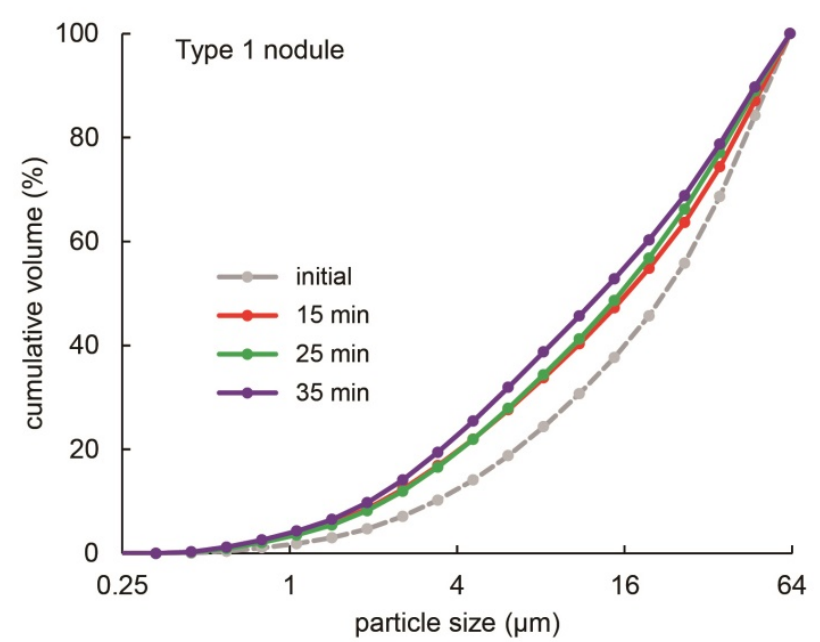

(a)

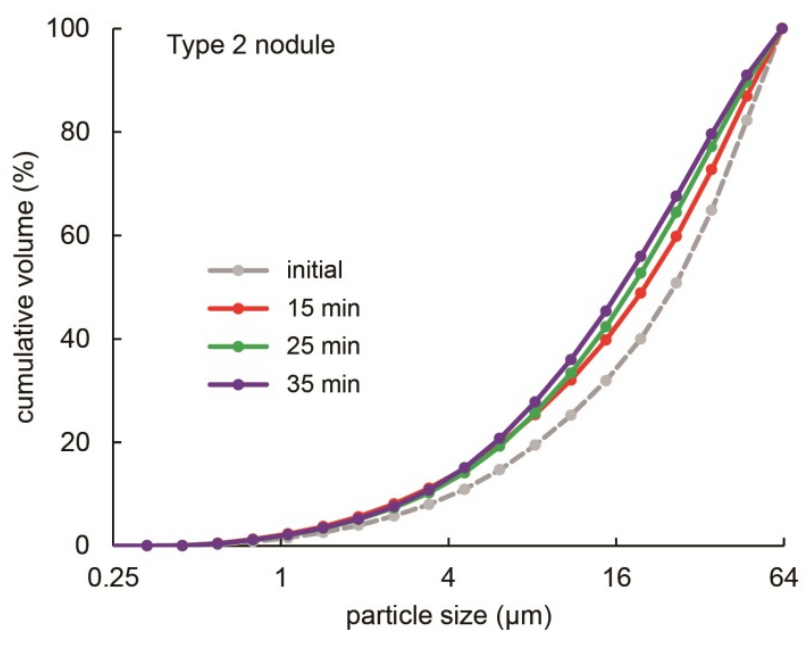

(b)

Figure 3. Particle size distributions of $<63 \mu \mathrm{m}$ particles produced by the degradation of (a) Type 1 nodules; (b) Type 2 nodules.

\subsection{Chemistry}

The average bulk composition of Type 1 and Type 2 nodules is presented in Tables 1 and 2 . As expected, the high $\mathrm{Mn} / \mathrm{Fe}$ ratio $(\approx 6.4)$ and high $\mathrm{Ni}$ and $\mathrm{Cu}$ contents of Type 1 nodules suggest their dominantly diagenetic origin, whereas the low $\mathrm{Mn} / \mathrm{Fe}$ ratio $(\approx 1.2)$ and high $\mathrm{Co}$ and Ce contents of Type 2 nodules indicate their dominantly hydrogenetic origin [5,29].

The chemical composition of the $<63 \mu \mathrm{m}$ particles from Type 1 nodules is given in Table 1. Compared to the bulk nodules, $\mathrm{Fe}, \mathrm{Al}, \mathrm{K}, \mathrm{Ti}$, and $\mathrm{Zr}$ are relatively abundant in the fines, whereas $\mathrm{Na}, \mathrm{Mn}, \mathrm{Co}, \mathrm{Ni}, \mathrm{Cu}, \mathrm{Zn}, \mathrm{As}, \mathrm{Mo}$, and $\mathrm{Cd}$ are generally deficient (Figure $4 \mathrm{a}-\mathrm{c}$ ). The deviation from the bulk nodule composition is usually most pronounced in the finest fraction $(<8 \mu \mathrm{m}$; red circles in Figure 4). The $\mathrm{Mn}, \mathrm{Ni}$, and $\mathrm{Cu}$ contents of the 32-63 $\mu \mathrm{m}$ fraction are about half of those of the bulk nodules, but the $<8 \mu \mathrm{m}$ fraction contains only about one-fifth of those of the bulk nodules. $\mathrm{P}, \mathrm{Ca}, \mathrm{Pb}$, and REEs show opposite patterns between different size fractions; they are generally abundant in the $32-63 \mu \mathrm{m}$ fraction and deficient in the $<8 \mu \mathrm{m}$ fraction compared to the bulk nodules.

The chemical composition of the $<63 \mu \mathrm{m}$ particles from Type 2 nodules is given in Table 2. Compared to the bulk nodules, $\mathrm{Fe}, \mathrm{Al}, \mathrm{Na}, \mathrm{P}$, and $\mathrm{K}$ are relatively abundant in the fines, whereas $\mathrm{Mn}, \mathrm{Ca}, \mathrm{Co}, \mathrm{Ni}, \mathrm{As}$, and $\mathrm{Mo}$ are generally deficient (Figure $4 \mathrm{~d}-\mathrm{f}$ ). The deviation from the bulk nodule composition is most pronounced in the finest fraction, but the compositional variation was generally smaller than in the case of Type 1 nodule fines. For example, the $\mathrm{Mn}$ and $\mathrm{Ni}$ contents of the $<8 \mu \mathrm{m}$ fines are reduced to half of those in the original nodules, which is relatively modest compared to the $\approx 80 \%$ decrease observed for $<8 \mu \mathrm{m}$ fines of Type 1 nodules. Some elements show opposite patterns between different size fractions; $\mathrm{Ti}, \mathrm{Cu}, \mathrm{Zn}, \mathrm{Cd}, \mathrm{Pb}$, and REEs are generally abundant in the $32-63 \mu \mathrm{m}$ fraction but deficient in the $<8 \mu \mathrm{m}$ fraction compared to the bulk nodules. 
Table 1. Major, trace, and rare earth element concentrations in Type 1 nodule fines.

\begin{tabular}{|c|c|c|c|c|c|c|c|c|c|c|c|c|c|c|}
\hline \multirow{2}{*}{ Element } & \multirow{2}{*}{$\begin{array}{c}\text { Bulk } \\
\text { Nodule }\end{array}$} & \multicolumn{4}{|c|}{15 Min } & \multicolumn{4}{|c|}{$25 \mathrm{Min}$} & \multicolumn{4}{|c|}{$35 \mathrm{Min}$} & \multirow{2}{*}{$\begin{array}{c}\text { Surface } \\
\text { Sediment }\end{array}$} \\
\hline & & $32-63$ & $16-32$ & $8-16$ & $<8 \mu \mathrm{m}$ & $32-63$ & $16-32$ & $8-16$ & $<8 \mu \mathrm{m}$ & $32-63$ & $16-32$ & $8-16$ & $<8 \mu \mathrm{m}$ & \\
\hline $\mathrm{Na}(\mathrm{wt} \%)$ & 2.16 & 0.87 & 1.05 & 0.8 & 1.3 & 0.85 & 0.77 & 0.97 & 0.11 & 1.11 & 1.16 & 1.18 & 1.13 & - \\
\hline $\mathrm{Mg}$ & 1.65 & 1.53 & 1.75 & 1.41 & 2.09 & 1.45 & 1.51 & 1.54 & 0.83 & 1.43 & 1.55 & 1.59 & 1.98 & 1.86 \\
\hline $\mathrm{Al}$ & 2.03 & 4.34 & 6.22 & 4.75 & 7.45 & 3.37 & 4.43 & 5.2 & 5.92 & 3.36 & 5.02 & 5.59 & 6.82 & 6.01 \\
\hline $\mathrm{P}$ & 0.14 & 0.26 & 0.11 & 0.13 & 0.15 & 0.22 & 0.15 & 0.12 & 0.13 & 0.25 & 0.19 & 0.13 & 0.08 & 0.14 \\
\hline $\mathrm{K}$ & 0.93 & 1.36 & 1.92 & 1.45 & 1.46 & 1.09 & 1.36 & 1.59 & 1.75 & 1.11 & 1.55 & 1.73 & 2.36 & 2.03 \\
\hline $\mathrm{Ca}$ & 1.32 & 1.5 & 1.22 & 1.08 & 1.01 & 1.55 & 1.24 & 1.32 & 0.8 & 1.55 & 1.36 & 1.23 & 0.8 & 0.81 \\
\hline $\mathrm{Ti}$ & 0.31 & 0.42 & 0.43 & 0.36 & 0.1 & 0.45 & 0.43 & 0.44 & 0.36 & 0.43 & 0.43 & 0.42 & 0.36 & 0.3 \\
\hline Mn & 28.55 & 15.47 & 8.22 & 9.12 & 5.6 & 17.2 & 12.26 & 11.41 & 6.77 & 17.52 & 12.29 & 9.5 & 6.9 & 0.43 \\
\hline $\mathrm{Fe}$ & 4.48 & 6.7 & 6.55 & 5.9 & 6.52 & 6.89 & 6.84 & 6.7 & 6.56 & 6.47 & 6.88 & 6.28 & 6.71 & 3.82 \\
\hline Co (ppm) & 1589 & 1442 & 826 & 996 & 538 & 1620 & 1326 & 1276 & 624 & 1549 & 1303 & 1004 & 693 & 67 \\
\hline Ni & 12161 & 5657 & 2689 & 3126 & 2017 & 6003 & 4159 & 4176 & 2577 & 5916 & 4163 & 3415 & 2712 & 156 \\
\hline $\mathrm{Cu}$ & 9839 & 4753 & 2578 & 2897 & 2152 & 4792 & 3376 & 3397 & 2468 & 4954 & 3736 & 2957 & 2449 & 406 \\
\hline $\mathrm{Zn}$ & 1300 & 674 & 451 & 455 & 446 & 705 & 556 & 542 & 545 & 730 & 602 & 482 & 426 & 130 \\
\hline As & 61 & 51 & 29 & 33 & 6 & 59 & 42 & 36 & 14 & 57 & 46 & 34 & 21 & 10 \\
\hline $\mathrm{Zr}$ & 228 & 297 & 310 & 251 & 315 & 330 & 284 & 288 & 306 & 290 & 303 & $\begin{array}{l}37 \\
299\end{array}$ & 297 & 161 \\
\hline Mo & 694 & 296 & 127 & 151 & 82 & 277 & 162 & 117 & 121 & 278 & 202 & 147 & 98 & - \\
\hline $\mathrm{Cd}$ & 19 & 7 & 4 & 4 & 3 & 7 & 5 & 5 & 2 & 8 & 5 & 4 & 3 & - \\
\hline $\mathrm{Pb}$ & 200 & 273 & 309 & 211 & 237 & 278 & 219 & 197 & 119 & 262 & 201 & 149 & 93 & 8 \\
\hline $\mathrm{La}(\mathrm{ppm})$ & 95 & 129 & 84 & 87 & 66 & 125 & 100 & 92 & 58 & 134 & 106 & 83 & 59 & 39 \\
\hline Ce & 338 & 387 & 261 & 277 & 190 & 441 & 369 & 339 & 195 & 447 & 359 & 282 & 195 & 71 \\
\hline $\mathrm{Pr}$ & 32 & 45 & 28 & 30 & 19 & 43 & 33 & 30 & 18 & 46 & 37 & 27 & 18 & 13 \\
\hline $\mathrm{Nd}$ & 126 & 190 & 110 & 117 & 79 & 182 & 131 & 120 & 71 & 192 & 143 & 112 & 68 & 54 \\
\hline $\mathrm{Sm}$ & 32 & 49 & 29 & 32 & 19 & 46 & 34 & 31 & 17 & 49 & 38 & 27 & 17 & 13 \\
\hline $\mathrm{Eu}$ & 8 & 14 & 8 & 9 & 5 & 12 & 9 & 8 & 5 & 13 & 10 & 8 & 5 & 4 \\
\hline $\mathrm{Gd}$ & 26 & 47 & 27 & 29 & 16 & 42 & 31 & 28 & 16 & 43 & 34 & 24 & 15 & 14 \\
\hline $\mathrm{Tb}$ & 4 & 8 & 4 & 5 & 2 & 7 & 5 & 4 & 2 & 7 & 5 & 4 & 2 & 2 \\
\hline Dy & 23 & 40 & 23 & 25 & 14 & 36 & 26 & 24 & 14 & 38 & 29 & 21 & 13 & 13 \\
\hline Y & 82 & 178 & 101 & 109 & 66 & 154 & 113 & 103 & 63 & 172 & 132 & 97 & 61 & 67 \\
\hline Ho & 4 & 8 & 4 & 5 & 3 & 7 & 5 & 4 & 3 & 7 & 5 & 4 & 2 & 3 \\
\hline $\mathrm{Er}$ & 12 & 22 & 12 & 13 & 8 & 19 & 14 & 13 & 7 & 21 & 15 & 11 & 7 & 7 \\
\hline $\mathrm{Tm}$ & 2 & 3 & 2 & 2 & 1 & 3 & 2 & 2 & 1 & 3 & 2 & 2 & 1 & 1 \\
\hline $\mathrm{Yb}$ & 11 & 20 & 11 & 12 & 7 & 18 & 13 & 12 & 7 & 19 & 14 & 11 & 7 & 7 \\
\hline $\mathrm{Lu}$ & 2 & 3 & 2 & 2 & 1 & 3 & 2 & 2 & 1 & 3 & 2 & 2 & 1 & 1 \\
\hline $\mathrm{Mn} / \mathrm{Fe}$ & 6.37 & 2.31 & 1.25 & 1.55 & 0.86 & 2.50 & 1.79 & 1.70 & 1.03 & 2.71 & 1.79 & 1.51 & 1.03 & 0.02 \\
\hline
\end{tabular}

${ }^{1}$ Kim et al. (2012) [26].

Table 2. Major, trace, and rare earth element concentrations in Type 2 nodule fines.

\begin{tabular}{|c|c|c|c|c|c|c|c|c|c|c|c|c|c|c|}
\hline \multirow{2}{*}{ Element } & \multirow{2}{*}{$\begin{array}{c}\text { Bulk } \\
\text { Nodule }\end{array}$} & \multicolumn{4}{|c|}{15 Min } & \multicolumn{4}{|c|}{25 Min } & \multicolumn{4}{|c|}{35 Min } & \multirow{2}{*}{$\begin{array}{c}\text { Surface } \\
\text { Sediment }\end{array}$} \\
\hline & & $32-63$ & $16-32$ & 8-16 & $<8 \mu \mathrm{m}$ & $32-63$ & $16-32$ & 8-16 & $<8 \mu \mathrm{m}$ & $32-63$ & $16-32$ & 8-16 & $<8 \mu \mathrm{m}$ & \\
\hline $\mathrm{Na}(\mathrm{wt} \%)$ & 1.41 & 2.95 & 3.33 & 3.21 & 2.82 & 2.94 & 3.34 & 3.2 & 2.73 & 2.85 & 3.38 & 0.38 & 2.86 & - \\
\hline $\mathrm{Mg}$ & 0.9 & 0.51 & 0.59 & 0.69 & 1 & 0.53 & 0.6 & 0.53 & 0.97 & 0.65 & 0.66 & 1.21 & 0.49 & 1.86 \\
\hline $\mathrm{Al}$ & 1.36 & 2.77 & 3.3 & 3.6 & 4.87 & 2.57 & 3.35 & 3.38 & 4.82 & 2.78 & 3.58 & 3.52 & 3.99 & 6.01 \\
\hline $\mathrm{P}$ & 0.44 & 1 & 1.82 & 1.49 & 0.88 & 1.02 & 1.77 & 1.32 & 0.96 & 1.39 & 1.84 & 0.66 & 1.12 & 0.14 \\
\hline $\mathrm{K}$ & 0.49 & 0.55 & 0.8 & 0.81 & 1.26 & 0.53 & 0.81 & 0.71 & 1.23 & 0.61 & 1.36 & 0.8 & 1.22 & 2.03 \\
\hline $\mathrm{Ca}$ & 2.04 & 0.91 & 0.75 & 0.7 & 0.61 & 0.92 & 0.71 & 0.69 & 0.36 & 2.11 & 0.92 & 0.87 & 0.43 & 0.81 \\
\hline $\mathrm{Ti}$ & 0.81 & 0.88 & 0.76 & 0.71 & 0.62 & 0.84 & 0.76 & 0.66 & 0.66 & 0.84 & 0.76 & 0.93 & 0.75 & 0.3 \\
\hline Mn & 16.39 & 17.33 & 12.84 & 10.55 & 9.21 & 16.03 & 12.35 & 11.05 & 8.58 & 14.7 & 11.98 & 10.54 & 9.34 & 0.43 \\
\hline $\mathrm{Fe}$ & 13.57 & 17.81 & 16.81 & 15.64 & 15.77 & 17.24 & 16.96 & 16.81 & 15.71 & 16.16 & 16.57 & 15.68 & 16.11 & 3.82 \\
\hline Co (ppm) & 4127 & 4017 & 3088 & 2311 & 2368 & 3746 & 3021 & 2445 & 2235 & 3316 & 2498 & 2512 & 2056 & 67 \\
\hline Ni & 3614 & 3616 & 2732 & 2366 & 2098 & 3306 & 2614 & 2402 & 1946 & 3037 & 2536 & 2636 & 2167 & 156 \\
\hline $\mathrm{Cu}$ & 748 & 914 & 708 & 607 & 543 & 855 & 682 & 628 & 514 & 807 & 603 & 647 & 504 & 406 \\
\hline $\mathrm{Zn}$ & 512 & 609 & 451 & 377 & 331 & 584 & 442 & 381 & 334 & 525 & 412 & 354 & 309 & 130 \\
\hline As & 175 & 150 & 103 & 84 & 82 & 141 & 101 & 78 & 62 & 142 & 37 & 25 & 242 & - \\
\hline $\mathrm{Zr}$ & 310 & 238 & 226 & 279 & 179 & 319 & 215 & 291 & 192 & 342 & 242 & 440 & 361 & 161 \\
\hline Mo & 362 & 306 & 224 & 194 & 157 & 281 & 218 & 190 & 148 & 315 & 274 & 254 & 192 & - \\
\hline $\mathrm{Cd}$ & 4 & 4 & 3 & 2 & 2 & 4 & 3 & 2 & 2 & 4 & 3 & 2 & 2 & - \\
\hline $\mathrm{Pb}$ & 793 & 1352 & 1020 & 876 & 733 & 1253 & 975 & 917 & 691 & 1235 & 1092 & 1014 & 853 & 8 \\
\hline $\mathrm{La}(\mathrm{ppm})$ & 198 & 221 & 138 & 100 & 73 & 201 & 127 & 99 & 68 & 280 & 141 & 103 & 61 & 39 \\
\hline $\mathrm{Ce}$ & 615 & 778 & 593 & 515 & 444 & 702 & 572 & 523 & 398 & 681 & 590 & 584 & 380 & 71 \\
\hline $\operatorname{Pr}$ & 36 & 44 & 27 & 16 & 11 & 39 & 24 & 15 & 10 & 52 & 22 & 18 & 9 & 13 \\
\hline $\mathrm{Nd}$ & 141 & 183 & 113 & 70 & 49 & 165 & 102 & 68 & 44 & 225 & 92 & 77 & 39 & 54 \\
\hline $\mathrm{Sm}$ & 28 & 38 & 23 & 17 & 11 & 34 & 21 & 16 & 11 & 45 & 22 & 18 & 9 & 13 \\
\hline $\mathrm{Eu}$ & 7 & 10 & 6 & 5 & 3 & 9 & 6 & 4 & 3 & 12 & 6 & 5 & 3 & 4 \\
\hline $\mathrm{Gd}$ & 29 & 45 & 29 & 24 & 17 & 41 & 26 & 23 & 16 & 55 & 28 & 26 & 13 & 14 \\
\hline $\mathrm{Tb}$ & 5 & 6 & 4 & 3 & 2 & 5 & 3 & 3 & 2 & 7 & 4 & 3 & 1 & 2 \\
\hline Dy & 26 & 34 & 22 & 20 & 14 & 31 & 20 & 18 & 13 & 41 & 23 & 21 & 11 & 13 \\
\hline Y & 154 & 206 & 132 & 90 & 59 & 186 & 115 & 80 & 53 & 315 & 133 & 98 & 45 & 67 \\
\hline Ho & 6 & 7 & 5 & 3 & 2 & 7 & 4 & 3 & 2 & 9 & 5 & 4 & 2 & 3 \\
\hline Er & 17 & 21 & 14 & 11 & 8 & 19 & 13 & 10 & 7 & 27 & 14 & 11 & 6 & 7 \\
\hline $\mathrm{Tm}$ & 3 & 3 & 2 & 2 & 1 & 3 & 2 & 2 & 1 & 4 & 2 & 2 & 1 & 1 \\
\hline $\mathrm{Yb}$ & 16 & 19 & 13 & 12 & 9 & 17 & 12 & 11 & 8 & 22 & 13 & 13 & 7 & 7 \\
\hline $\mathrm{Lu}$ & 2 & 3 & 2 & 2 & 1 & 3 & 2 & 2 & 1 & 4 & 2 & 2 & 1 & 1 \\
\hline $\mathrm{Mn} / \mathrm{Fe}$ & 1.21 & 0.97 & 0.76 & 0.67 & 0.58 & 0.93 & 0.73 & 0.66 & 0.55 & 0.91 & 0.72 & 0.67 & 0.58 & 0.02 \\
\hline
\end{tabular}

${ }^{1}$ Kim et al. (2012) [26]. 

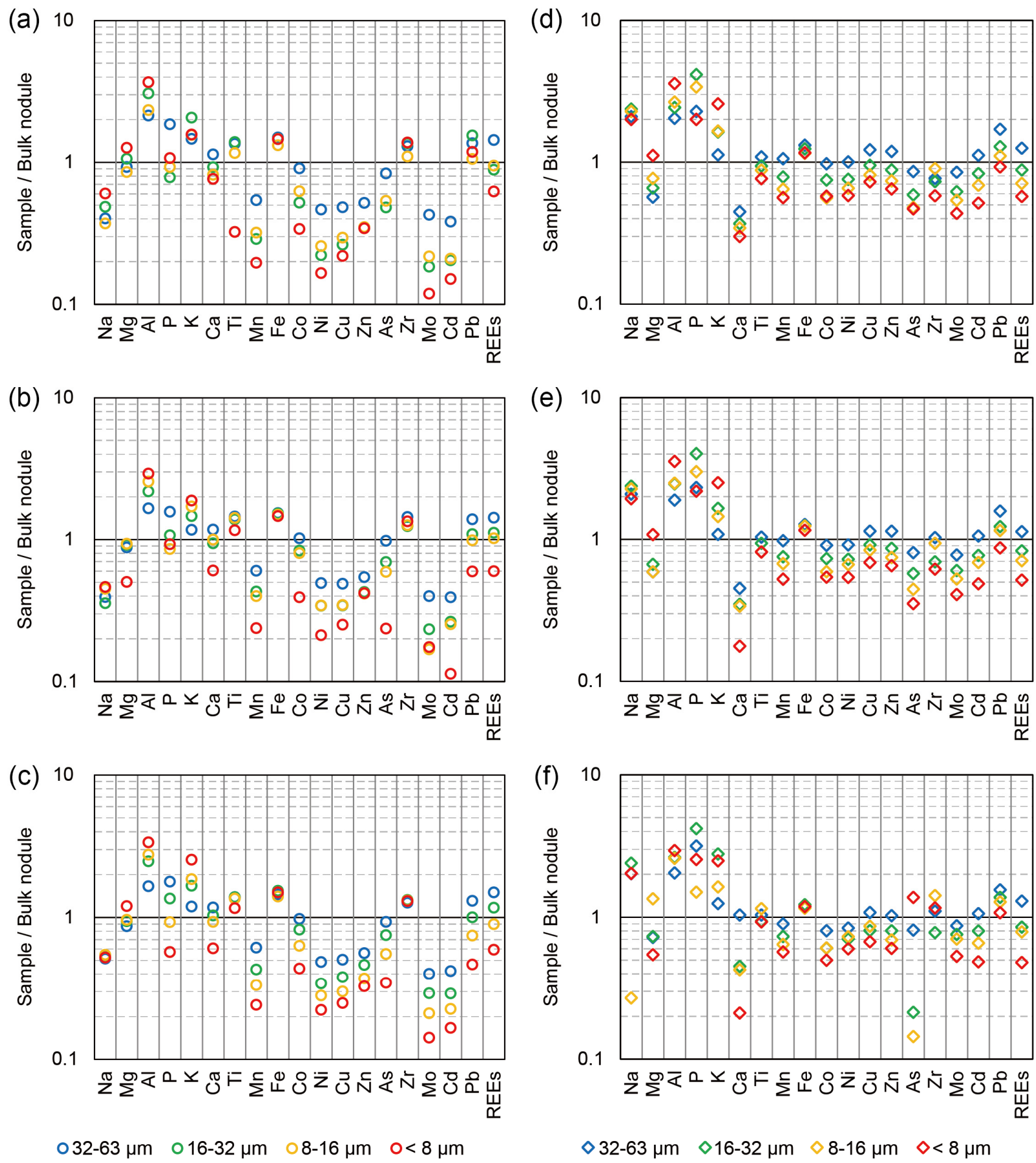

Figure 4. Relative abundance of elements (compared to the composition of bulk nodules) in fines produced from Type 1 nodules after (a) $15 \mathrm{~min}$, (b) $25 \mathrm{~min}$, and (c) $35 \mathrm{~min}$ of degradation and from Type 2 nodules after (d) $15 \mathrm{~min}$, (e) $25 \mathrm{~min}$, and (f) 35 min of degradation.

\subsection{Mineralogy}

Figure 5 shows the representative XRD patterns of Type 1 and Type 2 nodules and their fines. The diffraction patterns overall showed poor intensity resulting from nanosized, poorly crystalline $\mathrm{Mn}$ minerals [30]. A background increase owing to amorphous silica is inferred from a broad bulge at around $15-30^{\circ}$. Still, some differences in bulk XRD pattern are notable, particularly in combination with the variation in chemical composition. The 
XRD pattern of the bulk Type 1 nodules shows broad diffraction maximums at $\approx 10 \AA, \approx 7 \AA$, $\approx 5 \AA, \approx 2.45 \AA$, and $\approx 1.42 \AA$. Inferring from the typical mineralogy of diagenetic nodules, $\approx 10 \AA$ and $\approx 5 \AA$ peaks in the XRD pattern of Type 1 nodules can be attributed to the (001) and (002) reflections of $10 \AA$ Mn-phases (10 ̊ phyllomanganates/todorokite), and a peak at $\approx 7 \AA$ is attributed to the (001) reflection of $7 \AA$ phyllomanganates. On the other hand, the XRD pattern of the bulk Type 2 nodules shows only two broad reflections at $\approx 2.45 \AA$ and $\approx 1.42 \AA$, which are indicative of Fe-vernadite $\left(\delta-\mathrm{MnO}_{2}\right)$ typical for hydrogenetic nodules. In addition to different Fe-Mn (oxyhydr)oxide minerals, variable amounts of quartz and feldspar are detected. While they are identifiable in the XRD patterns of the bulk nodules, they occur in higher abundance in the nodule fines, particularly in the finer fractions. The detection and the quantification of clay minerals are limited due to their overlap with Fe-Mn (oxyhydr)oxides having reflections at similar positions, but peaks potentially attributable to illite and/or montmorillonite stand out in the $<8 \mu \mathrm{m}$ fines.
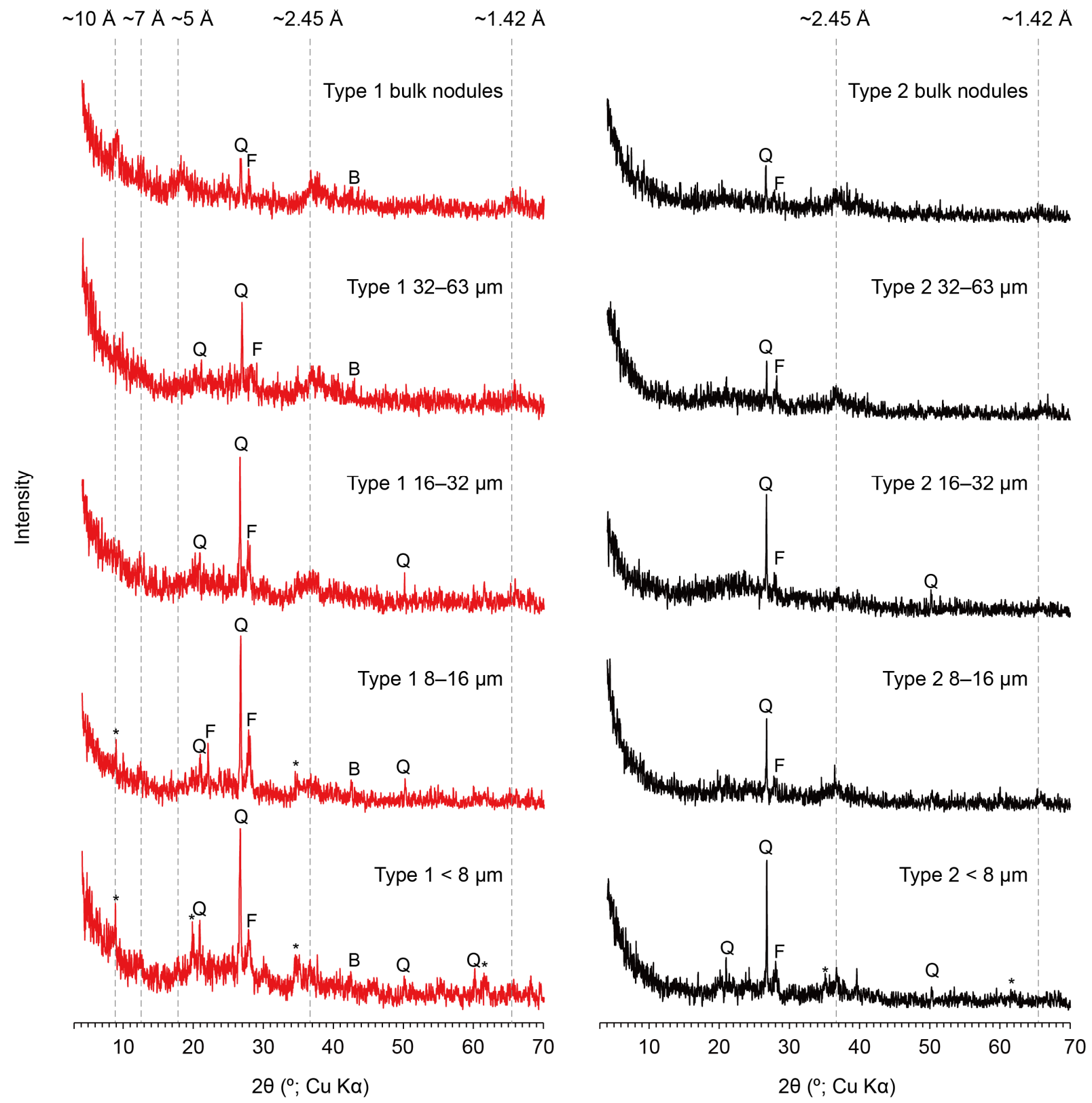

Figure 5. XRD patterns of Type 1 and Type 2 nodules and their fines (after 35 minutes of milling). Q $=$ quartz, $F=$ feldspar, $\mathrm{B}=$ barite. Star symbols indicate peaks that are potentially attributable to clay minerals. 


\section{Discussion}

\subsection{Causes of Compositional Variation}

Our investigation on experimentally produced fines of polymetallic nodules shows that their elemental composition differs widely from that of original nodules. Many elements exhibited similar partitioning trends in both nodule types: $\mathrm{Al}, \mathrm{K}$, and $\mathrm{Fe}$ are relatively enriched, whereas $\mathrm{Mn}, \mathrm{Co}, \mathrm{Ni}, \mathrm{As}, \mathrm{Mo}$, and $\mathrm{Cd}$ are depleted in the fines (Figure 4). The enrichment or depletion of each element is usually most noticeable in the finest fraction of particles $(<8 \mu \mathrm{m})$. The $\mathrm{Mn}$ and $\mathrm{Al}$ content in Type 1 nodules, which were $28.6 \%$ and $2.0 \%$, respectively, changed to $\approx 6.4 \%$ and $\approx 6.7 \%$ in the $<8 \mu \mathrm{m}$ fines, respectively. The $\mathrm{Mn}$ and $\mathrm{Al}$ content in Type 2 nodules, which were $16.4 \%$ and $1.4 \%$, respectively, changed to $\approx 9.0 \%$ and $\approx 4.5 \%$ in the $<8 \mu \mathrm{m}$ fines, respectively.

The above results suggest the selective incorporation of certain mineral phases in the $<63 \mu \mathrm{m}$ fraction. Indeed, the XRD patterns indicate the general increase in silicates and aluminosilicates in the fines (Figure 5). The most straightforward explanation for these observations is that sediment particles within the pores and cracks of nodules are released to form part of the fines. Abyssal sediments in the KODOS area as well as other nodule exploration areas in the CCZ have average grain size of about 3-30 $\mu \mathrm{m}$ [31-35]. Thus, it is reasonable to expect that sediment particles encapsulated in the nodules are mostly silts and clays as well. Once released, they will be concentrated in the $<63 \mu \mathrm{m}$ fraction in higher proportion than were in the bulk nodules.

Surface sediments in the KODOS area where the nodule samples were collected are dominated by quartz, feldspar, illite, smectite, and biogenic silica [26]. Sediments within the nodules may have somewhat different mineralogical composition, but a study from the UK license area in the CCZ have shown that quartz, feldspar, phillipsite, and various clay minerals make up a sizable portion in the bulk mineralogy of nodules [25]. The concentration of such minerals can explain the enrichment of $\mathrm{Al}$ and $\mathrm{K}$ in the nodule fines. It also effectively explains the greater decrease observed for Type 1 nodule fines in the abundance of most trace metals (e.g., $\mathrm{Mn}, \mathrm{Co}, \mathrm{Ni}, \mathrm{Cu}$; Figure 4), because more porous and fragile Type 1 nodules will likely release a greater amount of encapsulated sediments compared to the Type 2 nodules (Figure 3). Whether this can be generalized as a universal characteristic of dominantly diagenetic nodules in the CCZ needs further evaluation, but dendritic structures that frequently encapsulate sediment particles are typical for diagenetic layers, which precipitate in the sediment pores $[5,24,36]$.

While the concentration of detrital minerals in the $<63 \mu \mathrm{m}$ fraction seems to be responsible for a large part of compositional variability, it is possible that ferromanganese parts of nodules may also enter the fines unevenly. In particular, the enrichment of $\mathrm{Fe}$ in the nodule fines is noteworthy. Surface sediments in the KODOS area contain about $4 \mathrm{wt} \%$ of Fe, which is similar to the average Fe content of Type 1 nodules and much lower than that of Type 2 nodules (Tables 1 and 2). Yet the fines generated from both nodule types show consistently higher Fe content compared to the bulk nodules, suggesting that a certain Fe-rich phase is also concentrated in the $<63 \mu \mathrm{m}$ fraction. In the case of Type 1 nodules, this seems to be because the hydrogenetic parts of the nodules are preferentially incorporated into the fines. The observation that the relative abundance of $\mathrm{Co}$ in fines is not as low as those of $\mathrm{Mn}, \mathrm{Ni}$, and $\mathrm{Cu}$ is in line with this interpretation (Figure $4 \mathrm{a}-\mathrm{c}$ ). The mechanism underlying this selective incorporation is unclear, but one possibility lies in the secondary fillings of pore spaces within nodules. The idea is supported by the report that pore-filling materials of polymetallic nodules from the German license area in the CCZ mostly have a chemical composition that is typical for hydrogenetic precipitation with low Mn/Fe ratios [24,37]. In the case of Type 2 nodules, we suspect the preferential incorporation of iron (oxyhydr)oxides (e.g., ferrihydrite, goethite) over $\delta-\mathrm{MnO}_{2}$, but a more extensive investigation is required to answer this question properly, which is beyond the scope of this paper.

As detrital minerals become abundant, most of the potentially toxic elements such as copper, zinc, and cadmium show decreased concentration in the finer fractions. However, 
this is not exactly the case for lead. A lead content similar to or higher than that of the bulk nodules is observed for different size fractions of fines (Tables 1 and 2), which might be related to the dissolution and readsorption behavior of lead [38]. Together with the arsenic content that varies in a somewhat disorganized fashion, this highlights the need for a much more in-depth investigation of heavy metals in the nodule fines.

\subsection{Implications on the Nodule Mining}

The fines produced by the physical degradation of nodules and the sediments accidentally taken together with nodules have long been regarded as the two major components of the solids in discharge. A few studies have quantitatively assessed their amount. Ozturgut et al. (1981) [18], based on the on-site test results of the DOMES (Deep Ocean Mining Environmental Study) Project, estimated that the abraded nodule fragments and the entrained sediments in discharge will each amount to $5 \%$ and $20 \%$ of the total mass of the nodules produced, respectively. Yamazaki et al. (1991) [19] proposed 7\% and 13\% for the same parameters based on their laboratory experiments. Oebius et al. (2001) [7] estimated a much lesser amount: $1-2 \%$ and $\approx 4 \%$ of the nodule mass for the fines and the sediments, respectively. The large discrepancy between these previous estimates implies that the actual amount of mine tailings can vary greatly depending on the engineering system.

With the development of various technologies for polymetallic nodule mining (see [39] for examples), some types of miners are now expected to entrain minimal amounts of sediment. However, based on our results, it is inferred that not only sediments around the nodules but also sediments "inside" the nodules will contribute significantly to the discharge. The important difference between the two is that the former arises from incomplete screening in the nodule collection process, whereas the latter is mainly generated in the lifting process. In other words, the latter is strictly a part of the nodule fines. This means that even if a well-designed miner effectively rejects the sediments and collects only the nodules from the seafloor, the discharged materials can still contain a large amount of sediment particles later released from the nodules.

We also emphasize the importance of the recovery size of particles at the mining vessel for the reliable assessment of environmental impacts of the nodule fines. Many studies have already pointed out that upon discharge, the grain size distribution of tailings will be the most important factor that will largely determine the temporal and spatial scales of their impact $[6,40,41]$. Our results add that the composition of the fines as well as their amount will depend to a great extent on the recovery size of the particles. For example, about three times as many fines are to be discharged into the ocean if only $>64 \mu \mathrm{m}$ particles are retained, compared to the case of recovering all $>8 \mu \mathrm{m}$ particles produced in our experiment (Figure 3). At the same time, the discharged materials will contain up to several times higher concentrations of different toxic elements (Tables 1 and 2).

As of February 2021, 18 contracts for the exploration of polymetallic nodules, 16 of which are for exploration in the CCZ, have been granted by the ISA. The ISA is currently drafting regulations on the commercial exploitation of deep-sea mineral resources [42]. The latest Draft Regulations on Exploitation of Mineral Resources in the Area [43], in addition to the provisions on general obligations relating to the marine environment, specifically provide that discharge should not be made except where permitted in accordance with "The assessment framework for Mining Discharges as set out in the Guidelines", which brings the need to develop relevant guidelines in parallel to the regulations [44]. Insufficient scientific knowledge is one of the key challenges in developing the regulations and associated guidelines $[42,45,46]$, and the results of our study contribute to a better understanding of the degradation products of nodules. Further scientific research on various aspects of the mining discharge are encouraged in order to fill large knowledge gaps on the road to the sustainable exploitation of polymetallic nodules. 


\section{Conclusions}

The chemistry and mineralogy of the fines produced by the degradation of polymetallic nodules differ from those of the original nodules from which they derived, and they also differ by particle size. This clearly indicates that both the amount and the properties of the tailings to be discharged into the ocean will be heavily affected by the minimum recovery size of particles. We suggest that the sediment particles inside the pore space of nodules later released during the degradation are majorly responsible for the observed compositional variation. Their contribution to the discharge is expected be particularly important when mining diagenetic nodules. The possible difference in composition between sediments inside and outside the nodules and the (re)adsorption behavior of toxic heavy metals in the fines during the degradation should be further explored.

Author Contributions: Conceptualization, M.G.K., K.H. and I.S.; methodology, M.G.K., K.H. and I.S.; formal analysis, M.G.K.; investigation, M.G.K. and J.Y.L.; writing-original draft preparation, M.G.K.; writing-review and editing, K.H. and I.S.; visualization, M.G.K.; supervision, K.H. and C.M.Y.; funding acquisition, K.H. and C.M.Y. All authors have read and agreed to the published version of the manuscript.

Funding: This research was funded by the Korea Institute of Ocean Science and Technology, PE99923 and PE99924.

Acknowledgments: We thank Jaewoo Jung for his aid in XRD analysis. We also thank the editors and two anonymous reviewers for their constructive comments and suggestions to improve this manuscript.

Conflicts of Interest: The authors declare no conflict of interest.

\section{References}

1. Mero, J.L. The Mineral Resources of the Sea; Elsevier: Amsterdam, The Netherlands, 1965; p. 312.

2. Amos, A.F.; Roels, O.A. Environment aspects of manganese nodule mining. Mar. Policy 1977, 1, 156-163. [CrossRef]

3. Sharma, R. Deep-sea impact experiments and their future requirements. Mar. Georesources Geotechnol. 2005, 23, 331-338. [CrossRef]

4. Sparenberg, O. A historical perspective on deep-sea mining for manganese nodules, 1965-2019. Extr. Ind. Soc. 2019, 6, 842-854. [CrossRef]

5. Kuhn, T.; Wegorzewski, A.; Rühlemann, C.; Vink, A. Composition, formation, and occurrence of polymetallic nodules. In Deep-Sea Mining; Sharma, R., Ed.; Springer International Publishing: Basel, Switzerland, 2017; pp. 23-63.

6. Thiel, H.; Tiefsee-Umweltschutz, F. Evaluation of the environmental consequences of polymetallic nodule mining based on the results of the TUSCH Research Association. Deep-Sea Res. Part II-Top. Stud. Oceanogr. 2001, 48, 3433-3452. [CrossRef]

7. Oebius, H.U.; Becker, H.J.; Rolinski, S.; Jankowski, J.A. Parametrization and evaluation of marine environmental impacts produced by deep-sea manganese nodule mining. Deep-Sea Res. Part II-Top. Stud. Oceanogr. 2001, 48, 3453-3467. [CrossRef]

8. Schriever, G.; Thiel, H. Tailings and their disposal in deep-sea mining. In Proceedings of the 10th ISOPE Ocean Mining and Gas Hydrates Symposium, Szczecin, Poland, 22-26 September 2013.

9. Sharma, R. Deep-Sea Mining: Current Status and Future Considerations. In Deep-Sea Mining Resource Potential, Technical and Environmental Considerations; Sharma, R., Ed.; Springer International Publishing AG: Cham, Switzerland, 2018 ; pp. 3-21.

10. Burns, R.E. Assessment of environmental effects of deep ocean mining of manganese nodules. Helgol. Mar. Res. 1980, 33, 433-442. [CrossRef]

11. Lavelle, J.W.; Ozturgut, E.; Baker, E.T.; Swift, S.A. Discharge and surface plume measurements during manganese nodule mining tests in the North Equatorial Pacific. Mar. Environ. Res. 1982, 7, 51-70. [CrossRef]

12. International Seabed Authority. Recommendations for the Guidance of Contractors for the Assessment of the Possible Environmental Impacts Arising from Exploration for Polymetallic Nodules in the Area (ISBA/16/LTC/7); International Seabed Authority: Kingston, Jamaica, 2010.

13. Jones, D.O.; Kaiser, S.; Sweetman, A.K.; Smith, C.R.; Menot, L.; Vink, A.; Trueblood, D.; Greinert, J.; Billett, D.S.M.; Arbizu, P.M.; et al. Biological responses to disturbance from simulated deep-sea polymetallic nodule mining. PLoS ONE 2017, 12, e0171750. [CrossRef] [PubMed]

14. Christiansen, B.; Denda, A.; Christiansen, S. Potential effects of deep seabed mining on pelagic and benthopelagic biota. Mar. Policy 2020, 114, 103442. [CrossRef]

15. Beekman, W.J.; Meesters, G.M.; Scarlett, B.; Becker, T. Measurement of granule attrition and fatigue in a vibrating box. Part. Part. Syst. Charact. 2002, 19, 5-11. [CrossRef]

16. Pitchumani, R.; Zhupanska, O.; Meesters, G.M.; Scarlett, B. Measurement and characterization of particle strength using a new robotic compression tester. Powder Technol. 2004, 143, 56-64. [CrossRef] 
17. Van Wijk, J.M.; De Hoog, E. Size reduction of CCZ polymetallic nodules under repeated impact fragmentation. Results Eng. 2020, 7, 100154. [CrossRef]

18. Ozturgut, E.; Lavelle, J.W.; Ericson, B.H. Estimated discharge characteristics of a commercial nodule mining operation. Mar. Min. 1981, 3, 1-18.

19. Yamazaki, T.; Tsurusaki, K.; Handa, K. Discharge from manganese nodule mining system. In Proceedings of the First International Offshore and Polar Engineering Conference, Edinburgh, UK, 11-16 August 1991.

20. Choi, H.S.; Kang, J.S.; Chang, S.W.; Koh, S.M.; Um, I.K. Shattering ratio of manganese nodule and physical properties of powdered manganese nodule and sea bottom sediment. J. Miner. Soc. Korea 2007, 20, 277-287.

21. Yoon, C.H.; Kim, J.; Park, H.; Yoo, K. The distribution of particle size and composition of manganese nodule comminuted during lifting. Geosystem Eng. 2015, 18, 348-352. [CrossRef]

22. Van Wijk, J.M.; Haalboom, S.; De Hoog, E.; De Stigter, H.; Smit, M.G. Impact fragmentation of polymetallic nodules under deep ocean pressure conditions. Miner. Eng. 2019, 134, 250-260. [CrossRef]

23. De Hoog, E.; Van Wijk, J.M.; Wijnands, J.T.M.; Talmon, A.M. Degradation of polymetallic nodules during hydraulic transport under influence of particle-wall and particle-particle interaction. Miner. Eng. 2020, 155, 106415. [CrossRef]

24. Wegorzewski, A.V.; Kuhn, T. The influence of suboxic diagenesis on the formation of manganese nodules in the Clarion Clipperton nodule belt of the Pacific Ocean. Mar. Geol. 2014, 357, 123-138. [CrossRef]

25. Reykhard, L.Y.; Shulga, N.A. Fe-Mn nodule morphotypes from the NE Clarion-Clipperton Fracture Zone, Pacific Ocean: Comparison of mineralogy, geochemistry and genesis. Ore Geol. Rev. 2019, 110, 102933. [CrossRef]

26. Kim, J.; Hyeong, K.; Lee, H.B.; Ko, Y.T. Relationship between polymetallic nodule genesis and sediment distribution in the KODOS (Korea Deep Ocean Study) area, northeastern Pacific. Ocean Sci. J. 2012, 47, 197-207. [CrossRef]

27. Rajesh, S.; Gnanaraj, A.A.; Velmurugan, A.; Ramesh, R.; Muthuvel, P.; Babu, M.K.; Ramesh, N.R.; Deepack, C.R.; Atmanand, M.A Qualification tests on underwater mining system with manganese nodule collection and crushing systems. In Proceedings of the 9th Ocean Mining Symposium, Maui, HI, USA, 19-24 June 2011.

28. Sung, K.Y.; Min, C.H.; Kim, H.W.; Lee, C.H.; Oh, J.W.; Hong, S. Performance Test for the Manganese Nodule Crushing Equipment of the Deep Seabed Mining Robot 'MineRo'. Ocean Polar Res. 2014, 36, 19-24. [CrossRef]

29. Hein, J.R.; Koschinsky, A.; Kuhn, T. Deep-ocean polymetallic nodules as a resource for critical materials. Nat. Rev. Earth Environ. 2020, 1, 158-169. [CrossRef]

30. Wegorzewski, A.V.; Kuhn, T.; Dohrmann, R.; Wirth, R.; Grangeon, S. Mineralogical characterization of individual growth structures of Mn-nodules with different Ni+ Cu content from the central Pacific Ocean. Am. Min. 2015, 100, 2497-2508. [CrossRef]

31. Chi, S.B.; Hyeong, K.S.; Kim, J.U.; Kim, H.S.; Lee, G.C.; Son, S.K. Classification of deep-sea sediment by geotechnical properties from the KODOS area in the C-C Zone of the northeast equatorial Pacific. Ocean Polar Res. 2003, 25, 529-543. [CrossRef]

32. Chi, S.B.; Lee, H.B.; Hyeong, K.S.; Ju, S.J.; Lee, G.C.; Ham, D.J. Geotechnical properties of pelagic red clay in northeast equatorial Pacific. Sea 2008, 13, 286-294.

33. Min, W.G.; Kim, D.; Rho, H.S.; Chi, S.B.; Son, S.K. Distribution and variability of the meiobenthic assemblages near the Korean polymetallic nodule claim area of the Clarion-Clipperton Fracture zone (subequatorial NE Pacific). Ocean Sci. J. 2018, 53, 315-336. [CrossRef]

34. Gillard, B.; Purkiani, K.; Chatzievangelou, D.; Vink, A.; Iversen, M.; Thomsen, L. Physical and hydrodynamic properties of deep sea mining-generated, abyssal sediment plumes in the Clarion Clipperton Fracture Zone (eastern-central Pacific). Elementa 2019, 7, 5. [CrossRef]

35. Zawadzki, D.; Maciag, Ł.; Abramowski, T.; McCartney, K. Fractionation trends and variability of rare earth elements and selected critical metals in pelagic sediment from abyssal basin of NE Pacific (Clarion-Clipperton Fracture Zone). Minerals 2020, 10, 320. [CrossRef]

36. Menendez, A.; James, R.H.; Lichtschlag, A.; Connelly, D.; Peel, K. Controls on the chemical composition of ferromanganese nodules in the Clarion-Clipperton Fracture Zone, eastern equatorial Pacific. Mar. Geol. 2019, 409, 1-14. [CrossRef]

37. Blöthe, M.; Wegorzewski, A.; Müller, C.; Simon, F.; Kuhn, T.; Schippers, A. Manganese-cycling microbial communities inside deep-sea manganese nodules. Environ. Sci. Technol. 2015, 49, 7692-7700. [CrossRef]

38. Koschinsky, A.; Winkler, A.; Fritsche, U. Importance of different types of marine particles for the scavenging of heavy metals in the deep-sea bottom water. Appl. Geochem. 2003, 18, 693-710. [CrossRef]

39. Toro, N.; Jeldres, R.I.; Órdenes, J.A.; Robles, P.; Navarra, A. Manganese nodules in Chile, an alternative for the production of Co and $\mathrm{Mn}$ in the future-A review. Minerals 2020, 10, 674. [CrossRef]

40. Rolinski, S.; Segschneider, J.; Sündermann, J. Long-term propagation of tailings from deep-sea mining under variable conditions by means of numerical simulations. Deep-Sea Res. Part II-Top. Stud. Oceanogr. 2001, 48, 3469-3485. [CrossRef]

41. Cuvelier, D.; Gollner, S.; Jones, D.O.; Kaiser, S.; Arbizu, P.M.; Menzel, L.; Mestre, N.C.; Morato, T.; Pham, C.; Pradillon, F.; et al Potential mitigation and restoration actions in ecosystems impacted by seabed mining. Front. Mar. Sci. 2018, 5, 467. [CrossRef]

42. Levin, L.A.; Amon, D.J.; Lily, H. Challenges to the sustainability of deep-seabed mining. Nat. Sustain. 2020, 3, 784-794. [CrossRef]

43. International Seabed Authority. Draft Regulations on Exploitation of Mineral Resources in the Area (ISBA/25/C/WP.1); International Seabed Authority: Kingston, Jamaica, 2019.

44. International Seabed Authority. Comments on the Draft Regulations on Exploitation of Mineral Resources in the Area (ISBA/26/C/2); International Seabed Authority: Kingston, Jamaica, 2020. 
45. Jaeckel, A. Strategic environmental planning for deep seabed mining in the area. Mar. Policy 2020, 114, 103423. [CrossRef]

46. Ginzky, H.; Singh, P.A.; Markus, T. Strengthening the International Seabed Authority's knowledge-base: Addressing uncertainties to enhance decision-making. Mar. Policy 2020, 114, 103823. [CrossRef] 